\title{
The genetic structure of a columnar cactus with a disjunct distribution: Stenocereus gummosus in the Sonoran desert
}

\author{
R Clark-Tapia and F Molina-Freaner \\ Departamento de Ecología Funcional y Aplicada, Instituto de Ecología UNAM, Estación Regional del Noroeste, Apartado Postal 1354, \\ Hermosillo, Sonora, CP 83000, Mexico
}

\begin{abstract}
Stenocereus gummosus is a columnar cactus endemic to the Sonoran desert that exhibits a disjunct distribution: it is widely distributed in Baja California and restricted to a small coastal area in mainland Sonora. In this paper, we examine the genetic structure and the mating system of this species in order to explore the origin of the disjunction and describe aspects of the pollination biology. Flowers are nocturnal, pollinated mainly by sphingids and self-incompatible. Polymorphism for allozymes (11 loci) was relatively high $(P=75 \%)$ but moderate levels of heterozygosity were detected $\left(H_{\mathrm{o}}=0.103\right.$ and $\left.H_{\mathrm{e}}=0.261\right)$. Sonoran populations exhibited higher levels of genetic variation than peninsular populations. $H_{\mathrm{e}}$ declined with latitude when just peninsular
\end{abstract}

and two island populations are included. Substantial levels of inbreeding within populations $(f=0.60)$, moderate differentiation among populations $(\theta=0.10)$, and no evidence of isolation by distance were detected. The neighbor-joining phenogram showed Sonoran and island populations nested within peninsular populations. Mainland populations showed greater genetic similarity to island populations, supporting a dispersal hypothesis for the origin of the disjunction. Future studies using DNA markers are suggested in order to better understand the forces that have shaped the genetic structure of this species.

Heredity (2003) 90, 443-450. doi:10.1038/sj.hdy.6800252

Keywords: columnar cacti; dispersal; genetic structure; mating system; Sonoran desert; Stenocereus gummosus

\section{Introduction}

Historical patterns of gene flow and vicariance influence the genetic and phylogeographic structure of populations (Avise, 2000) and are two of the most important mechanisms invoked to explain the origin of spatially disjunct populations within species (Ronquist, 1997). Under the vicariance hypothesis, related populations become separated when the continuous range of ancestral forms is divided by environmental events such as the breakup of a continental landmass. In contrast, under the dispersal hypothesis, a disjunct distribution is caused by migration across a geographic barrier.

The present disjunct distribution of many Sonoran desert plant taxa on both sides of the Gulf of California (Turner et al, 1995) has intrigued plant biologists working in the area. These disjunctions led Cody et al (1983) to propose a dispersal hypothesis for the origin of Sonoran populations. According to Cody et al (1983), the Midriff Islands of the Gulf of California have functioned as a partial bridge for the migration of plant taxa from Baja to mainland Sonora. The Midriff Islands are located where the gulf is narrowest, forming a chain whose largest water gap is only $15 \mathrm{~km}$ (Cody et al, 1983; Lindsay, 1983),

Correspondence: F Molina-Freaner, Departamento de Ecología Funcional y Aplicada, Instituto de Ecología UNAM, Estación Regional del Noroeste, Apartado Postal 1354, Hermosillo, Sonora, CP 83000, Mexico.

E-mail: freaner@servidor.unam.mx

Received 22 April 2002; accepted 13 January 2003 making a plausible stepping-stone route for migration. On the other hand, major vicariance events undoubtedly occurred as a result of the physical separation of the Baja California peninsula from mainland México and the formation of the Gulf of California approximately 5 mya as a result of tectonic interactions between the North American and Pacific plates (Lonsdale, 1989). The peninsular region was isolated from mainland México by the northward transgression of the Gulf of California, thus creating an effective barrier for organisms with limited dispersal capacity (Murphy, 1983). The formation of the gulf may have fragmented range distributions and created disjunctions. As a consequence, the origin of disjunct populations could be due to dispersal or vicariant events. The vicariance hypothesis has been supported by studies on the genetic differentiation and phylogeographic structure of many vertebrate taxa from the region (Aguirre et al, 1999; Riddle et al, 2000a-c). However, very few plant taxa have been studied in this particular context (Nason et al, 2002).

The geographic distributions of Sonoran desert plants have also been influenced by long-term patterns of global climate change. Owing to their tropical origin many Sonoran desert taxa are frost sensitive (Shreve, 1964). Paleobotanical evidence derived from packrat middens have indicated that the geographic range of many plant taxa has been subject to expansion and contraction in response to climatic change (Van Devender, 1990, 2002). For a variety of organisms, the population genetic consequences of this cycle of range contraction and 
expansion from a single southern refuge have been a latitudinal trend in genetic diversity (Hewitt, 1996). Hewitt (1996) suggested that a common history of climatic change might cause correlated changes of expansion and contraction and thus concordant geographic patterns of genetic structure across species. For the columnar cactus Lophocereus schottii, the genetic structure exhibits latitudinal trends and genetic signatures of historical range expansion in Baja California but not in mainland Sonora (Nason et al, 2002). However, it is unknown if other columnar cacti from the region exhibit a concordant pattern.

Stenocereus gummosus is a diploid (Pinkava et al, 1977) columnar cactus endemic to the Sonoran desert (Gibson, 1989; Turner et al, 1995; see Figure 1). It is widely distributed in Baja California from the cape region up to Ensenada, is present on many islands in the Gulf of California, and in Sonora it is restricted to the coastal area between Bahía Kino and Desemboque (Turner et al, 1995). S. gummosus is a semierect shrub, mostly $1-1.5 \mathrm{~m}$ tall, having numerous rigid, ascending or arching branches that arise from near the ground. The species has both sexual and vegetative reproduction. Vegetative reproduction occurs by rooting from stem fragments forming small clonal colonies (Gibson, 1989). Flowers are white to purplish with a long $(10-15 \mathrm{~cm})$, narrow floral tube (Gibson, 1989; Turner et al, 1995). The sweet scent, nocturnal anthesis, and flower shape suggest pollination by hawkmoths (Gibson and Horak, 1978; Gibson, 1989). Other species of the genus are self-incompatible (Boyle,

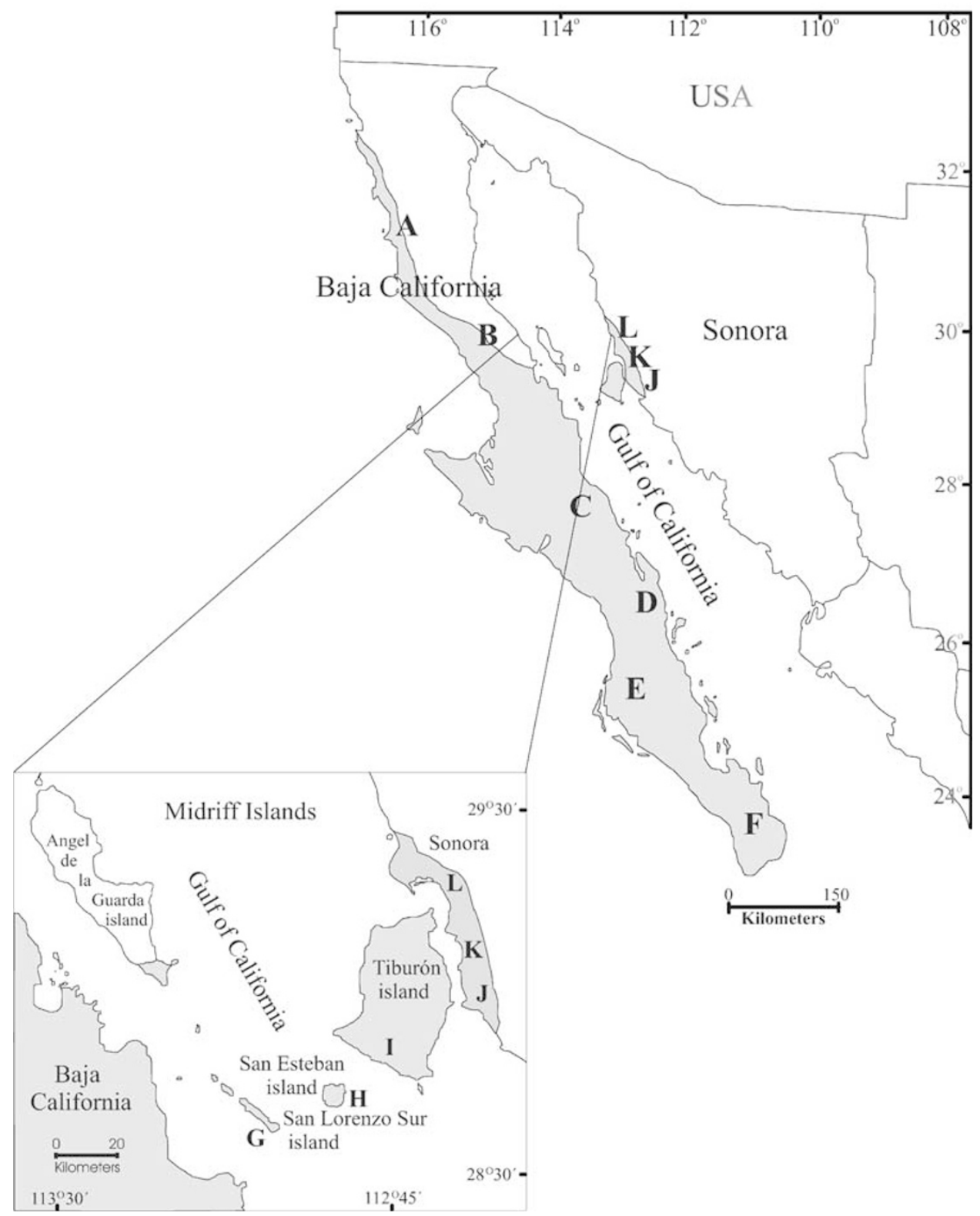

Figure 1 Map showing the range of distribution of S. gummosus in northwestern México and sampling localities. See Table 1 for population location. Modified from Turner et al (1995). 
1997). Little is known about seed dispersal, but it is well known that fruits are used by Indian groups of Baja California and Sonora (Felger and Moser, 1985; León de la Luz et al, 1995). Thus, our knowledge about the pollination biology, the relative importance of clonal versus sexual reproduction and the gene dispersal system of $S$. gummosus is rather poor.

In this paper, we describe geographic patterns of population genetic structure in order to test two hypotheses. First, we want to test the dispersal hypothesis proposed by Cody et al (1983) for the origin of the Sonoran populations of S. gummosus. If this hypothesis is correct, we expect greater genetic similarity between Sonoran and Midriff Island populations than between peninsular and Sonoran populations. Second, we test the hypothesis of concordant genetic structure among species subject to a common history of climatic change (Hewitt, 1996). If this hypothesis is correct, we expect latitudinal trends in the genetic diversity of S. gummosus.

Mating and gene dispersal systems are known to have important effects on the genetic structure of plant species (Hamrick and Godt, 1989). Knowing if a species is selfcompatible is important because it has important consequences for the organization of genetic variation within and among populations (Hamrick and Godt, 1989). Thus, in this paper we also describe some basic aspects of the pollination biology in order to provide evidence for the interpretation of the genetic structure of S. gummosus.

\section{Material and methods}

\section{Pollination biology}

We studied the basic aspects of the pollination biology of S. gummosus in one population occurring on the Sonoran coast. Based on accessability, we selected Punta Onah (Population K, Table 1 and Figure 1) to study flower anthesis, flower visitors, and the response to different pollination treatments. The abundance of $S$. gummosus in this population is within the range observed in coastal Sonora. S. gummosus flowers from June to December (León de la Luz et al, 1995, 1996). During the peak flowering time in 1998 (1-3 September), we selected five plants to describe flower anthesis by measuring the distance between opposite perianth tips begining at bud opening and up to flower closure, using one flower per plant every $30 \mathrm{~min}$. We recorded flower visitors during two nights using five focal flowers per night, in 5-min intervals every $30 \mathrm{~min}$. Flower visitors were collected with hand-nets and prepared for later identification. To determine whether flowers are self-compatible, we conducted a pollination experiment using 19-25 plants. Owing to low flower production, only three pollination

Table 1 Sampling localities and estimates of genetic variation within populations of S. gummosus

\begin{tabular}{|c|c|c|c|c|c|c|c|c|}
\hline Population/region & Latitude ${ }^{\circ} \mathrm{N}$ & Longitude ${ }^{\circ} \mathrm{W}$ & $\mathrm{N}$ & $\% \mathrm{P}$ & $\mathrm{A}$ & $\mathrm{H}_{o}$ & $\mathrm{H}_{e}$ & $\mathrm{~F}_{i s}$ \\
\hline \multicolumn{9}{|l|}{ Peninsular populations } \\
\hline A- EJIDO FRANCISCO VILLA, BC & $30^{\circ} 26^{\prime} 25^{\prime \prime}$ & $115^{\circ} 52^{\prime} 49^{\prime \prime}$ & 50 & 66.6 & 1.8 & 0.105 & 0.207 & 0.493 \\
\hline B- BAHIA DE LOS ANGELES, BC & $29^{\circ} 03^{\prime} 15^{\prime \prime}$ & $113^{\circ} 58^{\prime} 22^{\prime \prime}$ & 51 & 72.7 & 1.8 & 0.068 & 0.249 & 0.728 \\
\hline C- EL ABULON (SAN IGNACIO), BCS & $27^{\circ} 17^{\prime} 34^{\prime \prime}$ & $113^{\circ} 01^{\prime} 54^{\prime \prime}$ & 50 & 72.7 & 2.0 & 0.089 & 0.245 & 0.638 \\
\hline D- LORETO Km. 34, BCS & $26^{\circ} 15^{\prime} 12^{\prime \prime}$ & $111^{\circ} 29^{\prime} 29^{\prime \prime}$ & 50 & 72.7 & 1.9 & 0.095 & 0.246 & 0.619 \\
\hline E- SAN CARLOS, BCS & $24^{\circ} 54^{\prime} 45^{\prime \prime}$ & $111^{\circ} 59^{\prime} 28^{\prime \prime}$ & 50 & 72.7 & 2.1 & 0.067 & 0.236 & 0.717 \\
\hline F- SAN BARTOLO, BCS & $23^{\circ} 43^{\prime} 13^{\prime \prime}$ & $109^{\circ} 46^{\prime} 39^{\prime \prime}$ & 50 & 72.7 & 2.1 & 0.100 & 0.291 & 0.658 \\
\hline \multicolumn{9}{|l|}{ Island populations } \\
\hline G- SAN LORENZO ISLAND & $28^{\circ} 35^{\prime} 12^{\prime \prime}$ & $112^{\circ} 46^{\prime} 06^{\prime \prime}$ & 50 & 72.7 & 1.8 & 0.096 & 0.225 & 0.574 \\
\hline H- SAN ESTEBAN ISLAND & $28^{\circ} 40^{\prime} 34^{\prime \prime}$ & $112^{\circ} 35^{\prime} 50^{\prime \prime}$ & 49 & 72.7 & 1.9 & 0.063 & 0.224 & 0.707 \\
\hline I- TIBURÓN ISLAND & $28^{\circ} 44^{\prime} 57^{\prime \prime}$ & $112^{\circ} 18^{\prime} 25^{\prime \prime}$ & 50 & 81.8 & 2.0 & 0.111 & 0.293 & 0.634 \\
\hline \multicolumn{9}{|l|}{ Mainland populations } \\
\hline J- SANTA ROSA, SONORA & $28^{\circ} 58^{\prime} 37^{\prime \prime}$ & $112^{\circ} 09^{\prime} 12^{\prime \prime}$ & 50 & 81.8 & 2.1 & 0.147 & 0.280 & 0.476 \\
\hline K- PUNTA ONAH, SONORA & $29^{\circ} 05^{\prime} 21^{\prime \prime}$ & $112^{\circ} 09^{\prime} 20^{\prime \prime}$ & 50 & 81.8 & 2.1 & 0.175 & 0.351 & 0.505 \\
\hline L- CERRO PINTO, SONORA & $29^{\circ} 23^{\prime} 48^{\prime \prime}$ & $112^{\circ} 17^{\prime} 10^{\prime \prime}$ & 50 & 81.8 & 2.1 & 0.120 & 0.290 & 0.588 \\
\hline Mean & & & 50 & 75.2 & 2.0 & 0.105 & 0.261 & 0.608 \\
\hline SD & & & & 5.2 & 0.1 & 0.037 & 0.041 & 0.050 \\
\hline \multicolumn{9}{|l|}{ Region } \\
\hline \multicolumn{9}{|l|}{ Peninsula } \\
\hline Population mean & & & & 71.7 & 2.0 & 0.087 & 0.246 & 0.642 \\
\hline SD & & & & 2.5 & 0.1 & 0.016 & 0.027 & 0.085 \\
\hline \multicolumn{9}{|l|}{ Island } \\
\hline Population mean & & & & 75.7 & 1.9 & 0.090 & 0.247 & 0.638 \\
\hline SD & & & & 5.3 & 0.1 & 0.025 & 0.040 & 0.066 \\
\hline \multicolumn{9}{|l|}{ Mainland } \\
\hline Population mean & & & & 81.8 & 2.1 & 0.156 & 0.307 & 0.523 \\
\hline $\mathrm{SD}$ & & & & 0 & 0 & 0.031 & 0.040 & 0.058 \\
\hline
\end{tabular}

$\mathrm{N}$, number of individuals sampled per population; $\% P$, percentage of polymorphic loci (99\% criterion); $A$, average number of alleles per polymorphic locus; $H_{\mathrm{o}}$, observed heterozygosity; $H_{\mathrm{e}}$, expected heterozygosity, and $F_{\mathrm{is}}$ measures deviation from Hardy-Weinberg proportion. SD is the standard deviation. BC: Baja California; BCS: Baja California Sur. 
treatments with one flower per treatment were employed. Pollination treatments were: (a) self-pollinated flowers ( $n=21$ flowers on 21 plants, one per plant); flower buds were bagged with bridal veil netting and soon after the flowers opened and pollen was released, they were hand pollinated using pollen from the same flower, (b) cross-pollinated flowers ( $n=19$ flowers on 19 plants); flower buds were bagged and when flowers opened they were hand pollinated by saturating the stigma with fresh pollen obtained from another plant at least $20 \mathrm{~m}$ away, and (c) open-pollinated flowers ( $n=25$ flowers on 25 plants); flowers that opened during three consecutive nights and available to any visitor were tagged. The fate (aborted or developing fruit) of the tagged flowers from pollination treatments was scored 45 days later. Mature fruits were collected in October and once in the lab they were opened, and the air-dried pulp and seeds were separated and the number of seeds per fruit was counted. We explored whether pollination treatments differ in fruit set and number of seeds per fruit through a $\chi^{2}$ test, using JMP version 3.2 (SAS Institute, 1997).

\section{Sampling and electrophoretic procedures}

Given that our objective is to test the dispersal hypothesis of Cody et al (1983), we sampled the entire range of distribution of the species, for a total of 12 populations (Figure 1, Table 1). We sampled six populations from Baja California, three from the Midriff Islands, and three from coastal Sonora. In each population, we took a small (2$3 \mathrm{~cm}^{3}$ ) tissue sample of rib chlorenchyma from each of 50 individuals, using a cork borer. Population density varied from 20 to 90 plants/ha among populations. In every population samples were collected haphazardly; sampled individuals were separated at least 5-10 m, and were collected by exploring an area of 200-300 m long. Samples were immediately stored in liquid nitrogen and once in the lab, they were transfered to an ultracold freezer $\left(-80^{\circ} \mathrm{C}\right)$.

Each tissue sample was ground in a cold mortar with $300 \mu \mathrm{l}$ of the phosphate-polyvinylpyrrolidone (PPVP) extraction buffer of Mitton et al (1979). The extract was absorbed onto $2 \times 10 \mathrm{~mm}$ filter paper wicks that were inserted in cooled $12 \%$ starch and $5 \%$ sucrose gels. Three buffer systems were used to assay 11 enzyme systems. Enzyme systems were selected on the basis of resolution and reproducibility. Buffer 6 of Wendel and Weeden (1989) was used to assay glucose-6-phosphate dehydrogenase (G6PDH), malate dehydrogenase (MDH), phosphoglucoseisomerase (PGI), esterase (EST), alcohol dehydrogenase $(\mathrm{ADH})$, glutamate dehydrogenase $(\mathrm{GDH})$, and diaphorase (DIA). Buffer system D of Stuber et al (1988) was used to assay acid phosphatase (ACP), phosphoglucosemutase (PGM), and menadione reductase (MNR). Buffer system PP of Mitton et al (1977) was used to assay leucine aminopeptidase (LAP). Staining protocols followed Wendel and Weeden (1989) for G6PDH, MDH, EST, ADH, and GDH; Morden et al (1987) for LAP, ACP, PGM, and PGI; and Stuber et al (1988) for MNR and DIA. Genetic interpretation of the banding patterns was based on the body of knowledge about the genetics of isozymes in diploid plants (Weeden and Wendel, 1989). Loci and alleles were designated based on relative band mobility, with lower numbers assigned to those farther away from the origin.

\section{Data analysis}

The matrix of genotypes across loci, individuals, and populations was analyzed using TFPGA (Miller, 1997). This program was used to obtain the percentage of polymorphic loci $(P)$, mean number of alleles per locus $(A)$, observed heterozygosity $\left(H_{\mathrm{o}}\right)$ and expected heterozygosity $\left(H_{\mathrm{e}}\right)$. Within-populations estimates were averaged over all populations and by region to obtain means and standard deviations. We explored whether $P, A, H_{\mathrm{o}}$ and $H_{\mathrm{e}}$ show regional differences through a KruskalWallis test, using JMP, version 3.2 (SAS Institute, 1997). A Fisher exact test $(R \times C)$ was used to test if allelic frequencies differ among populations using TFPGA. Simple regression analysis was used to explore if $H_{\mathrm{e}}$ is affected by latitude, using JMP, version 3.2 (SAS Institute 1997). Wright $F$ coefficients $\left(F_{\text {is, }} F_{\text {st }}\right.$, and $\left.F_{\text {it }}\right)$ were calculated using TFPGA (Miller, 1997). $F_{\text {is }}$ and $F_{\text {it }}$ are measures of the deviation from Hardy-Weinberg proportions within subpopulations and in the total population, respectively, while $F_{\text {st }}$ is a measure of the genetic differentiation over subpopulations. Wright F-parameters and their 95\% confidence intervals were estimated following the methods of Weir and Cockerham (1984) ( $f, \theta$, and $F$, respectively). Standard deviations of the estimates were obtained by jackknifing over loci and confidence intervals by bootstrapping over loci (Miller, 1997). Isolation by distance was analyzed with the method proposed by Slatkin (1993) based on an island model. A Mantel test (1000 permutations) was used to test the significance of the correlation between pairwise $M(\theta)$ and geographic (straight-line) distance matrices. Nei's (1978) genetic distances were estimated between all pairs of populations and the matrix used to construct a neighbor joining (Saitou and Nei, 1977) phenogram using PHYLIP, version 3.572 (Felsenstein, 1995). A total of 1000 bootstrap samples over loci were used to estimate the confidence of the branch points.

\section{Results}

\section{Pollination biology}

In Punta Onah, flowers of S. gummosus were nocturnal; they started to open between 20:00 and 21:00 h (local time) and were fully open by midnight (23:00-24:00 h). Perianth tips began to close around $400 \mathrm{~h}$ and flowers were totally closed early in the morning (7:00-8:00 h). We recorded a total of five flower visitors during the night and early morning. The sphingids, Hyles lineata and Erinnyis ello, and an unknown moth started to visit early when flowers were opening while another sphingid, Manduca quinquemaculata, visited the flowers after 22:00 $\mathrm{h}$. This group of nocturnal visitors was active from 20:00 to 3:00 h with mean visitation rates of $0.5-2.5$ visits / flower $/ 5 \mathrm{~min}$, making contact with stigma and anthers. $H$. lineata was also active from $4: 00$ to $6: 00 \mathrm{~h}$ with visitation rates of $0.5-1.5$ visits/flower $/ 5 \mathrm{~min}$, while honeybees (Apis mellifera) visited the flowers from 6:00 to $8: 00 \mathrm{~h}$ with mean visitation rates of 3.6 visits/flower/ $5 \mathrm{~min}$. None of the hand self-pollinated flowers set fruit, indicating self-incompatibility. Fruit set and number of seeds per fruit for the hand cross-pollination treatment were $0.42 \pm 0.49($ mean \pm SD) and $641 \pm 197(n=8)$, and $0.60 \pm 0.49$ and $604 \pm 144(n=15)$ for the open-pollinated control flowers. Differences between these treatments 
were not significant for fruit set $\left(\chi^{2}=1.39, P=0.23\right)$ nor for seeds/fruit $\left(\chi^{2}=0.40, P=0.53\right)$.

\section{Genetic variation}

Nine of 11 loci were polymorphic (81.8\%) in at least one population, while DIA-1 and LAP-1 were monomorphic in all populations. Polymorphism $(P)$ ranged from 66 to $82 \%$ and mean number of alleles per locus $(A)$ from 1.8 to 2.1 among populations with mean values of 75 and $1.9 \%$, respectively (Table 1 ). Three low-frequency alleles (PGI1d, APC-2c, and MNR-2c) were detected only in Baja California and were absent in Sonora and island populations while one allele (PGM-2b) was detected only in Sonora and Tiburón island but absent in Baja and the other two islands. Observed heterozygosity $\left(H_{\mathrm{o}}\right)$ varied from 0.06 to 0.18 and expected heterozygosity $\left(H_{\mathrm{e}}\right)$ from 0.21 to 0.35 among populations and the average values were 0.10 and 0.26 , respectively (Table 1 ). Sonoran populations had slightly greater levels of genetic variation (Table 1). However, significant differences among regions were detected just for $P$ (Kruskal-Wallis $H=7.65$, $P=0.02)$ and $H_{\mathrm{o}}(H=6.27, P=0.04)$ and not for $A$ $(H=4.52, P=0.10)$ and $H_{\mathrm{e}}(H=3.08, P=0.21)$. Linear regression analysis indicated that latitude had no significant effect on $H_{\mathrm{e}}$ when all populations were included $\left(F=0.006, P=0.93, r^{2}=0.0006\right.$, see Figure 2$)$. However, when just peninsular populations and two islands close to Baja (San Lorenzo and San Esteban) were included, a significant effect was detected $(F=9.4$, $P=0.02, r^{2}=0.61$, Figure 2)

\section{Genetic structure}

Significant allele frequency heterogeneity among populations was detected for all polymorphic loci $\left(\chi^{2}=178.2\right.$, $P<0.001) . H_{\mathrm{o}}$ was considerably lower than $H_{\mathrm{e}}$ in all populations suggesting a deficiency of heterozygotes in the species. In consequence, $F_{\text {is }}$ was positive for all populations, indicating an excess of homozygotes (Table 1). No significant differences were detected for $F_{\text {is }}$ values among regions (Kruskal-Wallis $H=3.92$,

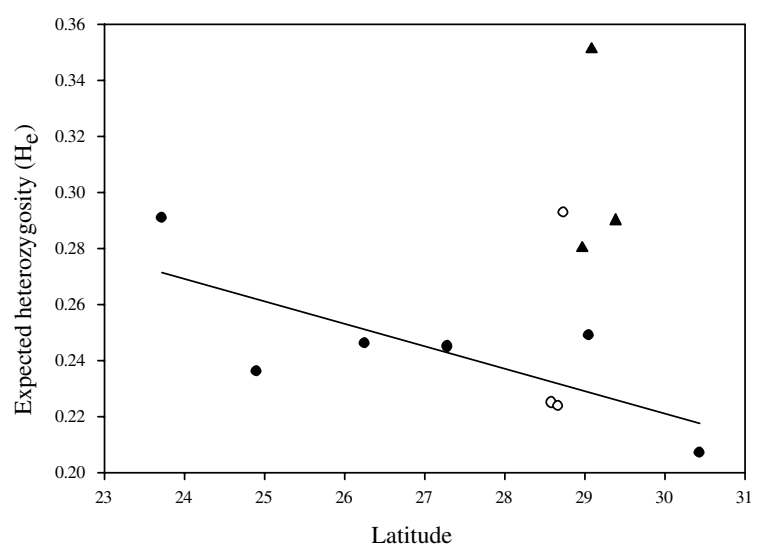

Figure 2 Expected heterozygosity $\left(H_{\mathrm{e}}\right)$ as a function of latitude $\left(^{\circ}\right)$ in populations of $S$. gummosus. Peninsular populations are indicated by filled circles, island populations by open circles, and mainland populations by filled triangles. Linear regression analysis indicates a significant effects of latitude when just peninsular populations and two islands close to baja (San Lorenzo and San Esteban) are included $\left(r^{2}=0.61\right)$.
$P=0.14)$. Mean values $( \pm 1 S D)$ of $F_{\text {is }}, F_{\mathrm{it}}$, and $F_{\text {st }}$ were $0.61 \pm 0.05,0.65 \pm 0.05$, and $0.10 \pm 0.03$, respectively. The $95 \%$ confidence intervals for $F_{\text {is }}, F_{\text {it }}$ and $F_{\text {st }}$ were $0.46-$ $0.71,0.50-0.74$, and $0.04-0.18$, respectively, indicating that these parameters are significantly greater than zero. Overall, these results indicate substantial heterozygosity deficits within populations and moderate variation in allele frequencies among populations.

No pattern of isolation by distance was detected when all populations were analyzed (Mantel test, $r=0.06$, $P=0.61)$ or when just peninsular populations were included (Mantel test, $r=0.20, P=0.76$ ). Thus, the population structure of this species does not appear to be due to differences in gene flow produced by isolation by geographic distance. Genetic distances ranged from 0.02 to 0.07 among populations with a mean value of 0.04 . The neighbor-joining phenogram constructed using Nei's (1978) genetic distances (Figure 3) indicates that Sonoran and Midriff Island populations are nested within peninsular populations. That is, Sonoran populations show greater genetic similarity to island populations than populations from Baja.

\section{Discussion}

In this study, we have shown that at least one population of S. gummosus is self-incompatible, and pollinated mainly by sphingid moths. Moderate levels of genetic variation and substantial deviations from Hardy-Weinberg proportions were found within populations, while moderate differentiation was observed among populations. The neighbor-joining phenogram partially supports the dispersal hypothesis of Cody et al (1983) for the origin of the Sonoran populations, while the evidence on latitudinal trends of genetic diversity provides partial support for the concordance hypothesis of Hewitt (1996) for species sharing a common environmental history.

The mating system of $S$. gummosus seems consistent with predictions based on flower morphology (Gibson and Horak, 1978; Gibson, 1989) and the distribution of self-incompatibility in the family (Boyle, 1997). As in other diploid members of the Pachycereeae (Boyle, 1997),

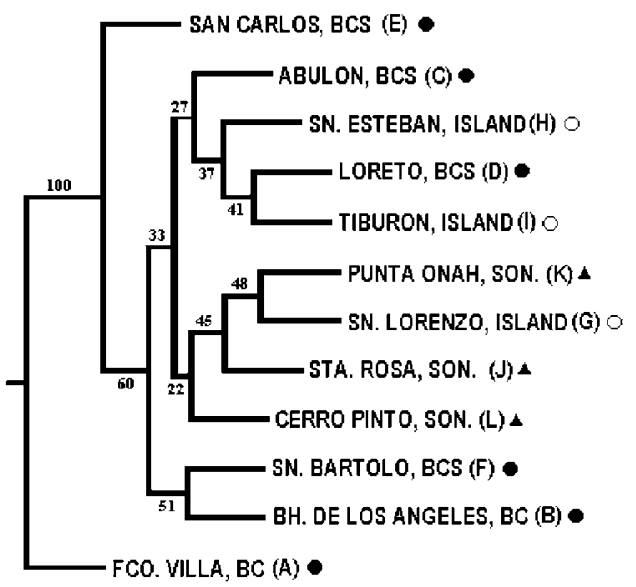

Figure 3 Neighbor-joining phenogram based on Nei's genetic distances $(D)$ among populations of $S$. gummosus. Numbers represent the percentage of bootstrap values (1000 replications) supporting the branch. 
one population of S. gummosus is self-incompatible, and thus selfing is unlikely to be a major cause of inbreeding. Three sphingid species were observed visiting flowers and depositing pollen on stigmas in one population from Sonora. Although a formal pollinator exclusion experiment is needed to infer the relative importance of sphingids versus honeybees, the available evidence suggests that sphingids are the major pollinators of Sonoran populations of S. gummosus.

Levels of genetic variation in populations of $S$. gummosus are within the range or slightly greater than that observed for other columnar cacti (Table 2, Nassar et al, 2001; Hamrick et al, 2002). However, in contrast to other columnar cacti present on both sides of the gulf (Hamrick et al, 2002), mainland populations of $S$. gummosus exhibit slightly greater levels of genetic variation than peninsular populations. At present, we do not know the mechanism responsible for this pattern. Nonetheless, the fact that the populations exhibiting greater variation (see outliers in Figure 2) coincide with the actual area of occupation of the Seri Indians (Felger and Moser, 1985) seems to suggest human influences. The Seri Indians harvest and consume fresh fruits of this species in great numbers (Felger and Moser, 1985) and are known to transplant plant material to camping sites (Roberto Molina, Punta Chueca, Sonora, personal communication). Thus, Seri Indians may be moving plant material between Tiburon and Sonora, and by introducing selected plants could be increasing the levels of variation in this region.

Differentiation among populations of S. gummosus $\left(F_{\mathrm{st}}\right)$ falls within the range observed for other columnar cacti, but $F_{\text {is }}$ is actually higher (Table 2). Actual levels of differentiation may reflect high levels of contemporary gene flow or recent range expansion of populations of $S$. gummosus. Under island and stepping-stone models of population structure, $F_{\text {st }}$ is inversely proportional to the average effective rate of gene flow among populations (Hart and Clark, 1997). Thus, pollination systems associated with lower values of $F_{\text {st }}$ imply greater potential for pollen gene flow. In this context, levels of differentiation among columnar cacti show association with dispersal abilities of pollen vectors (Hamrick et al, 2002). For instance, the high levels of differentiation observed for L. schottii have been attributed to the limited dispersal ability of its pollinator, the moth Upiga virescens (Fleming and Holland, 1998). In contrast, other columnar cacti pollinated by vectors of greater potential for pollen flow (bats, birds, and bees) exhibit lower differentiation among populations (Table 2, Hamrick et al, 2002). For $S$. gummosus, the value of $\theta(0.10)$ was closer to columnar cacti with generalized pollination systems involving bats, birds, and bees than to L. schott $i$ with its specialized moth pollination system (Table 2). So, if the level of differentiation observed for columnar cacti reflects real differences in dispersal abilities of pollen vectors, then the sphingid species responsible for pollinating $S$. gummosus may mediate pollen flow similar to that of the more generalized pollination systems. Sphingids are known for their long-distance flights (Janzen, 1984) and thus this result is not unexpected. On the other hand, the failure to detect isolation by distance could imply recent range expansion of populations of $S$. gummosus or that isolation by distance occurs at a smaller scale than the distances employed in this study.

One of the most striking results of this study is the high level of $F_{\text {is }}$ detected within populations (Table 1). Selfing can be excluded as a possible source of inbreeding as we found evidence of self-incompatibility at least for one population. However, mating among relatives, genetic subdivision (Turner et al, 1982), homozygote advantage, clonal structure, and/or geographic variation in the mating system could be generating such levels of deviation from Hardy-Weinberg proportions. One plausible explanation of the high values of $F_{\text {is }}$ could be isolation by distance within populations. If this is the case, sampling several subpopulations within each population could also account for the relatively low value of $F_{\text {st }}$ among populations.

The neighbor-joining phenogram and the distribution of low-frequency alleles provide partial support for the dispersal hypothesis of Cody et al (1983) for the origin of the Sonoran population. Gibson (1989) suggested two speciation scenarios for the origin of $S$. gummosus. Assuming that $S$. stellatus from the Pacific coast is the sister taxa, an allopatric model could have operated if the two clades were isolated when Baja California split from mainland México (Gibson, 1989). The second scenario

Table 2 Levels of genetic variation within and among population of columnar cacti from México and Venezuela

\begin{tabular}{|c|c|c|c|c|c|c|c|}
\hline \multirow[t]{2}{*}{ Species } & \multicolumn{4}{|c|}{ Genetic variation within populations } & \multicolumn{2}{|c|}{$F$ statistics } & \multirow[t]{2}{*}{ Pollinators } \\
\hline & $\% \mathrm{P}$ & A & $\mathrm{H}_{o}$ & $\mathrm{H}_{e}$ & $\mathrm{f}$ & $\theta\left(\mathrm{G}_{S T}\right)$ & \\
\hline Carnegiea gigantea ${ }^{\mathrm{a}}$ & 53.7 & 2.20 & 0.110 & 0.116 & 0.057 & 0.075 & Bats, birds and bees ${ }^{f}$ \\
\hline Lophocereus schottii ${ }^{\mathrm{b}}$ & 50.0 & 2.30 & 0.142 & 0.151 & 0.009 & 0.352 & Moth (Upiga virescens) \\
\hline Pachycereus pringlei ${ }^{\mathrm{a}}$ & 62.1 & 2.50 & $*$ & 0.200 & $*$ & 0.076 & Bats, birds \& bees $^{f}$ \\
\hline Stenocereus thurberi ${ }^{\mathrm{a}}$ & 62.4 & 2.36 & 0.157 & 0.169 & 0.036 & 0.128 & Bats, birds and bees ${ }^{f}$ \\
\hline Melocactus curvispinus ${ }^{c}$ & 89.5 & 3.82 & - & 0.145 & 0.348 & 0.193 & Hummingbird ${ }^{c}$ \\
\hline Pereskia guamacho & 63.4 & 2.42 & 0.169 & 0.202 & 0.196 & 0.112 & Bees $^{\mathrm{a}}$ \\
\hline Stenocereus griceus ${ }^{\mathrm{a}}$ & 57.1 & 2.36 & 0.139 & 0.167 & 0.202 & 0.096 & Bats $^{\mathrm{d}}$ \\
\hline Stenocereus gummosus & 81.8 & 2.20 & 0.103 & 0.290 & 0.608 & 0.102 & Sphingids \\
\hline
\end{tabular}

${ }^{*}$ P. pringlei is autotetraploid. ${ }^{\mathrm{a}}$ Hamrick et al (2002). ${ }^{\mathrm{b}} \mathrm{Nason}$ et al (2002). cNassar et al (2001). ${ }^{\mathrm{d} N a s s a r}$ et al (1997). ${ }^{\mathrm{F}}$ Fleming and Holland (1998).

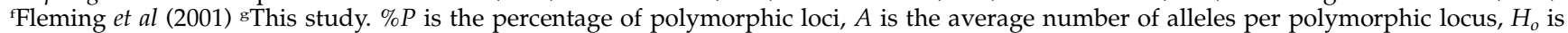
observed heterozygosity, and $H_{e}$ is the expected heterozygosity, $f$ is a measure of deviation from Hardy-Weinberg proportion at the subpopulation level and $\theta\left(G_{\mathrm{ST}}\right)$ measures genetic differentiation among populations. Estimates of $f$ and $\theta$ include a combination of Weir and Cockerham (1984) and Nei's (1977) estimators. 
involves a vicariance model where $S$. gummosus evolved as a northern coastal species before the formation of the gulf and became fragmented through sea-floor spreading (Gibson, 1989). The dispersal hypothesis of Cody et al (1983) for the origin of mainland populations is compatible with just the first speciation scenario of Gibson (1989), and the vicariance model is an alternative for the origin of the disjunction. Our data partially support the dispersal hypothesis as peninsular populations have more low-frequency alleles absent in mainland and Sonoran and Midriff Island populations exhibited greater genetic similarity and were nested within peninsular populations. Given that the peninsula has been moving in a northward direction (Lonsdale, 1989), under a vicariant model without migration and without range expansion and contraction, we would expect greater genetic similarities between mainland and peninsular populations of different latitudes. However, the phenogram shows no evidence of such pattern. Thus, from the sizeable group of plant taxa suggested by Cody et al (1983) to have reached mainland Sonora through the Midriff Islands, at least one species (S. gummosus) partially supports the dispersal hypothesis.

Our results provide partial support for the hypothesis of Hewitt (1996) for a concordant genetic structure across species subject to a common environmental history. For L. schottii, Nason et al (2002) found evidence of significant declines in genetic variation with increasing latitude only in Baja and area phenograms in which populations are progressively nested from south (ancestral) to north (descendant) along the Baja peninsula. For S. gummosus, our evidence also indicates a significant reduction in $H_{\mathrm{e}}$ just for peninsular and two island populations (Figure 2). Thus, if during periods of range contraction and expansion, southern populations functioned as refuges and recolonization involved frequent bottlenecks (Nei et al, 1975), we expect northern populations to have reduced levels of genetic variation. Clearly, more peninsular populations need to be sampled in order to explore if $S$. gummosus exibits a robust pattern across latitude.

In this paper, we have provided evidence about processes affecting the genetic structure of S. gummosus. To make further progress in understanding the genetic structure, we suggest studies using more powerful DNA markers, especially a combination of nuclear and cytoplasmic markers in order to infer the relative importance of seed versus polen flow. We also suggest studying the geographic variation in the mating system in order to understand the forces generating significant deviations from Hardy-Weinberg within populations. These studies will provide stronger evidence about the forces that have shaped the genetic structure of $S$. gummosus.

\section{Acknowledgements}

We thank John Nason, Luis Eguiarte, and Daniel Piñero for critical comments and suggestions on earlier versions of the manuscript, Grethel Ramírez, Antonio Hernández, Conrado Valenzuela, Mauricio Cervantes, and Jesus Vargas for lab and field assistance. Financial support was provided by Papiit-DGAPA-UNAM (project IN211997), CONABIO (R187), and a CONACYT scholarship to RCT.

\section{References}

Aguirre LG, Morafka DJ, Murphy RW (1999). The peninsular archipelago of Baja California: a thousand kilometers of tree lizard genetics. Herpetologica 55: 369-381.

Avise JC (2000). Phylogeography The History and Formation of Species. Harvard University Press: Cambridge, MA.

Boyle TH (1997). The genetics of self-incompatibility in the genus Schlumbergera (Cactaceae). J Hered 88: 209-214.

Cody M, Moran R, Thompson H (1983). The plants. In: Case TJ, Cody ML (eds) Island Biogeography in the Sea of Cortéz, University of California Press: Berkeley, CA. pp 49-97.

Felger RS, Moser MB (1985). People of the Desert and Sea: Ethnobotany of the Seri Indians. University of Arizona Press: Tucson, AZ.

Felsenstein J (1995). PHYLIP (Phylogeny Inference Package) version 3.572. Department of Genetics, University of Washington, Seattle, WA, USA.

Fleming TH, Holland JN (1998). The evolution of obligate mutualisms: the senita and senita moth. Oecologia 114: 368378.

Fleming TH, Sahley CT, Holland JN, Nason JD, Hamrick JL (2001). Sonoran desert columnar cacti and the evolution of generalized pollination systems. Ecological Monographs 71: 511-530.

Gibson AC (1989). The systematics and evolution of the subtribe Stenocereinae 7. The machaerocerei of Stenocereus. Cact Succulent J 61: 104-112.

Gibson AC, Horak KE (1978). Systematic anatomy and phylogeny of Mexican columnar cacti. Ann M Bot Gard 65: 999-1057.

Hamrick JL, Godt MJ (1989). Allozyme diversity in plant species. In: Brown AHD, Clegg MT, Kahler AL, Weir BS. (eds) Plant Population Genetics, Breeding and Genetic Resources, Sinauer Associates: Sunderland, MA. pp 43-63.

Hamrick JL, Nason JD, Fleming TH (2002). Genetic diversity in columnar cacti. In: Fleming TH, Valiente-Banuet A (eds) Evolution, Ecology and Conservation of Columnar Cacti and Their Mutualists, University of Arizona Press: Tucson, AZ.pp 122-133.

Hart DL, Clark AG (1997). Principles of Population Genetics. 3rd edn. Sinauer Associates: Sunderland, MA

Hewitt GM (1996). Some genetic consequences of ice ages, and their role in divergence and speciation. Biol J Linnean Soc $\mathbf{5 8}$ 247-276.

Janzen DH (1984). Two ways to be a big moth: Santa Rosa saturniids and sphingids. Oxford Surv Evol Biol 1: 85-140.

León de la Luz JL, Coria-Benet R, Cruz-Estrada M (1996). Fenología floral de una comunidad árido-tropical de Baja California Sur, México. Acta Bot Mex 35: 45-64.

León de la Luz JL, Domínguez-Cadena R, Cruz-Estrada M, Rodríguez-Estrella R (1995). Reproductive phenology of Stenocereus gummosus (Engelm.) Gibson \& Horak. Implications for its cultivation. Genet Res Crop Evol 42: 61-67.

Lindsay GE (1983). History of scientific exploration in the sea of Cortéz. In: Case TJ, Cody ML (eds) Island Biogeography in the Sea of Cortéz, University of California Press: Berkeley, CA. pp 3-12.

Lonsdale P (1989). Geology and tectonic history of the Gulf of California. In: Winterer EL, Hussong DM, Decker RW (eds) The Eastern Pacific Ocean and Hawaii: The Geology of North America, Geological Society of America: Boulder, CO. pp 449521.

Miller MP (1997). Tools for Population Genetic Analysis (TFPGA, 1.3). A windows program for the analysis of allozyme and molecular population genetic data. Software distributed by author.

Mitton JB, Linhart YB, Hamrick JL, Beckman JS (1977). Observations on the genetic structure and mating system of ponderosa pine in the Colorado front range. Theor Appl Genet 51: 5-13. 
Mitton JB, Linhart YB, Sturgeon KB, Hamrick JL (1979) Allozyme polymorphism detected in mature needle tissue of ponderosa pine. J Hered 70: 86-89.

Morden CW, Doebley JF, Schertz KF (1987). A Manual of Techniques for Starch Gel Electrophoresis of Sorghum Isozymes. Texas Agricultural Experimental Station Miscellaneous publication No. 1635. College Station, TX.

Murphy R (1983). The reptiles: origins and evolution. In: Case TJ, Cody ML (eds) Island Biogeography in the Sea of Cortéz, University of California Press: Berkeley, CA. pp 130-158.

Nason JD, Hamrick JL, Fleming TH (2002). Historical vicariance and postglacial colonization effects on the evolution of genetic structure in Lophocereus, a Sonoran desert columnar cactus. Evolution 56: 2214-2226.

Nassar JM, Ramírez N, Linares O (1997). Comparative pollination biology of Venezuelan columnar cacti and the role of nectar-feeding bats in their sexual reproduction. American Journal of Botany 84: 918-927.

Nassar JM, Hamrick JL, Fleming TH (2001). Genetic variation and population structure of the mixed-mating cactus, Melocactus curvispinus (Cactaceae). Heredity 87: 69-79.

Nei M (1978). Estimation of average heterozygosity and genetic distance from a small number of individuals. Genetics 89: 583-590.

Nei M, Maruyama T, Chakraborty R (1975). The bottleneck effect and genetic variability in populations. Evolution 29: 1-10.

Pinkava DJ, McGill LA, Reeves T, McLeod MG (1977). Chromosome numbers in some cacti of western North America. III. Bull Torrey Bot Club 104: 105-110.

Riddle BR, Hafner DJ, Alexander LF (2000a). Phylogeography and systematics of the Peromyscus eremicus group and the historical biogeography of North American warm regional deserts. Mol Phylogenet Evol 17: 145-160.

Riddle BR, Hafner DJ, Alexander LF (2000b). Comparative phylogeography of Baileys' pocket mouse (Chaetodipus baileyi) and the Peromyscus eremicus species group: historical vicariance of the Baja California peninsular desert. Mol Phylogenet Evol 17: 161-172.

Riddle BR, Hafner DJ, Alexander LF, Jaeger JF (2000c). Cryptic vicariance in the historical assembly of a Baja California peninsular desert biota. Proc Nat Acad Sci 97: 14438-14443.
Ronquist F (1997). Dispersal-vicariance analysis: a new approach to the quantification of historical biogeography. Syst Biol 46: 195-203.

Saitou N, Nei M (1977). The neighbor-joining method: a new method for reconstructing phylogenetic trees. Mol Biol Evolution 4: 406-425.

SAS Intitute (1997). JMP Statistical Software Package, version 3.2 edition, SAS Institute Inc: Cary, NC.

Shreve F (1964). Vegetation of the Sonoran desert. In: Shreve F, Wiggins IL (eds) Vegetation and Flora of the Sonoran Desert, Stanford University Press: Stanford, CA. pp 3-186.

Slatkin M (1993). Isolation by distance in equilibrium and nonequilibrium populations. Evolution 47: 264-279.

Stuber CW, Wendel JF, Goodman MM, Smith JSC (1988). Techniques and Scoring Procedures for Starch Gel Electrophoresis of Enzymes from Maize (Zea mays L.). Technical Bulletin 286. North Carolina Agricultural Research Service, North Carolina State University, Raleigh, NC.

Turner ME, Stephens JC, Anderson WW (1982). Homozygosity and patch structure in plant populations as a result of nearest-neighbor pollination. Proc Nat Acad Sci 79: 203-207.

Turner RM, Bowers JE, Burgess TL (1995). Sonoran Desert Plants. University of Arizona Press: Tucson, AZ.

Van Devender TR (1990). Late quaternary vegetation and climate of the Sonoran desert, United States and México. In: Betancourt JL, Van Devender TR, Martin PS (eds) Packrat Middens: The last 40,000 Years of Biotic Change. University of Arizona Press: Tucson, AZ. pp 134-164.

Van Devender TR (2002). Environmental history of the Sonoran desert. In: Fleming TH, Valiente-Banuet A (eds) Evolution, Ecology and Conservation of Columnar Cacti and Their Mutualists, University of Arizona Press: Tucson, AZ. pp 3-24.

Weeden NF, Wendel JF (1989). Genetics of plant isozymes. In: Soltis DE, Soltis PS (eds) Isozymes in Plant Biology, Dioscorides Press: Portland, OR. pp 46-72.

Weir BS, Cockerham CC (1984). Estimating F-statistic for the analysis of population structure. Evolution 38: 1358-1370.

Wendel JF, Weeden NM (1989). Visualization and interpretation of plant isozymes. In: Soltis DE, Soltis PS (eds) Isozymes in Plant Biology, Dioscorides Press: Portland, OR. pp 5-45. 